\title{
The Role of the Maternal Archetype in the Work of Flannery O’Connor
}

\author{
Natalie Ales \\ Brigham Young University, Provo, USA
}

\begin{abstract}
This paper explores the motivations behind the behaviors of characters in the work of renowned southern writer, Flannery O'Connor, and displays that these characters behave the way that they do because of their relationships with their mothers. Herein the author investigates Attachment Theory, a theory regarding the human need to connect with caregivers and nurturers in childhood, and-through a psychological lens-how this principle influences the grown characters in O'Connor's work. In an examination of the prevalent archetype of "The Great Mother" in her stories, namely "The Lame Shall Enter First", “The Enduring Chill”, and "Parker's Back", we can see the effects of secure-or confident, warm and reliable-parent-child attachment as well as the effects of insecure - unstable and unreliable - attachment. These different attachment styles contribute to the lifelong development of different behaviors and even personalities in the characters of Norton, Asbury, and O.E. Parker. In the cases above mentioned, the relationship between characters and their maternal figures contribute not only to the plot of the story, but also to the fate of the characters - driving them to do things that are often extreme and climactically catalytic. It proves that parent-child relationships have lasting psychological effects, and, in the case of O'Connor's work, spiritual ones as well. O'Connor is well known for the religious morals of her works, and in this study it is ultimately evident that the relationships between characters and their maternal figures reflect and influence each character's relationship with and attitude towards Deity.
\end{abstract}

Keywords: mother, family, maternal archetype, attachment, Flannery O'Connor, psychology, child development, relationships

Critics of O'Connor such as Ann E. Reuman speculate as to whether O'Connor's relationship with her mother played into the creation of some of her stories. In her article, Revolting Fictions: Flannery O'Connor's Letter to Her Mother, Reuman writes of O'Connor's description of an encounter with her mother in which her mother was critical of her work and quotes O’Connor saying, "this always leaves me shaking and speechless, raises my blood pressure 140 degrees..." (Reuman, 1993, p. 206). While it is beyond the scope of this paper to talk about O'Connor's relationship with her mother, this quote shows that relations with mothers were on O'Connor's mind. Indeed, mothers are a symbol found throughout her works. Of such symbols, mothers and others, O'Connor $(1969$, p. 71) herself said, "[They] operate in depth as well as on the surface... the truer the symbol, the deeper it leads you, the more meaning it opens up... the fact that these meanings are there makes the book significant. The reader may not see them now, but they have their effect on him nonetheless". Not only do O'Connor's works contain the archetype of "the mother", but an examination of how that symbol

Natalie Ales, Brigham Young University. 
impacts her characters through attachment theory can give us deeper insight into the motivations and instincts that drive their sometimes extreme and unexpected actions. Additionally, it is this "effect" on the reader, above mentioned by O'Connor herself, that is particularly fueled by these symbols. The research and perspective offered in this paper suggests (although it does not deeply examine) that O'Connor's works may impact readers as profoundly as they do because of the presence of the maternal archetype.

The attachment of a child to it's mother greatly impacts the way that a child views the world and all of the other relationships in their lives. Most of our knowledge on attachment is derived from what is called Attachment Theory - an idea proposed by a man named John Bowlby. His work, along with the work of his female associate Mary Ainsworth, has since greatly influenced psychological understanding in this field. Attachment is defined as "the strong, affectionate tie we have with special people in our lives that leads us to experience pleasure and joy when we interact with them and to be comforted by their nearness in times of stress" (Berk, 2013, p. 428). Another definition supports this one, stating that, "attachment is the foundation of self-control, personality, and emotional well-being" (C. C. Bergin \& D. A. Bergin, 2015, p. 240). Scientists believe that from the time of infancy all the way up through adulthood, the emotional attachments between people and caregivers or other critical relations greatly impact human development and well-being (Yee \& Shiota, 2015, p. 220). This is because, in their natural development, infants first attach to their mothers, and it is this first and primary relationship that helps them to initially assess their relationship to the world. Cassidy (2000), in the journal Psychological Inquiry, said, "a central notion of Attachment Theory is that early in life, humans develop mental representations of themselves, the people important in their lives, and the workings of the world" (p. 88). Phycologists refer to this perception of the world in relation to the individual as the "internal working model". According to Berk, distinguished author and professor of psychology, the internal working model is a "vital part of personality" that serves, as she goes on to say, "as a guide for all future relationships" (Berk, 2013, p. 430). This means that a child develops all of their future relationships based on the skills and perceptions that they developed through their experiences with attachment figures. Essentially, these early attachments can impact the personality and sociability of a person forever. An examination of how these very concepts are evident in O'Connor's works provides great insight into the psychology of her characters and her readers, and ultimately supplies insight into a child's natural yearning to please the almighty care-giver: God.

\section{The Maternal Archetype}

The archetype of the mother, so prevalent in literature and culture, can be seen in both a positive and a negative light. De Coster (2010) expounds on this in his work, "The Collective Unconscious and its Archetypes" when he says, "To most humans... certain archetypal qualities seem good and others seem bad. We are attracted to the 'positive' creating, nurturing aspects of Mother, for example, but terrified of her 'negative' qualities such as her terrible, fierce, possessiveness or her power of life and death over us" (p. 4). A prime example of this dichotomy is the idea of Mother Nature. She is always viewed as associated with life, abundance, and fertility, and yet, as De Coster goes on, she is also the "bringer of death" (De Coster, 2010, p. 29). Springing from this idea are the two main archetypes of mother: the "Good Mother" and the "Terrible Mother" (Guerin et al., 2011, p. 228). Interestingly, attachment is also divided into two categories-secure and insecure attachment. Secure attachment is associated with mothers who are sensitive and responsive to children's needs, while insecure attachment has been found to be associated with rejection or inconsistent nurturing on the part of the mother (Kindvatter \& Desmond, 2013, p. 105). In other words, the "Good 
Mother" - the one who brings life and abundance - does so because of her nurturing and demonstration of responsiveness to her child. This provides a secure mother-child attachment that is conducive to such positive results as those affiliated with the archetypal "Good Mother". The "Terrible Mother" on the other hand, is linked to the ideas of death and dismay because of the feelings of insecurity, rejection, abandonment, and confusion experienced by children who are not parented in a way that contributes to a secure and healthy mother-child attachment. These feelings project themselves onto a child's behavior and psychology forever - and thus can have weighty consequences. In the works of Flannery O'Connor we can not only see traces of both archetypes, but we can also see the attachment situations that give each archetype effect.

\section{The Good Mother}

The typical archetype of the Good Mother is associated with things such as life, birth, warmth, nourishment, and abundance (Guerin et al., 2011, p. 228). One example of the Good Mother archetype is in the story The Lame Shall Enter First. This story is about a father named Shepard and his son Norton. Norton suffers still from losing his mother over a year previous to the start of the story, and Shepard is preoccupied with helping a troubled teen named Rufus Johnson. Here, one must recognize that traumatic events such as death can lead to various struggles in a child's life, and that Norton's situation is complicated and tragic. Rather than explore further the effects that losing a guardian can have on children, this paper will focus on the family dynamics surrounding Norton and the still-apparent power of the Maternal archetype in his life and in his home. Therefore, although this research does not encompass all possible factors in Norton's development, for the purpose of the examination of the maternal archetype in this context, this paper proceeds to apply principles of attachment.

Norton, an eleven-year-old boy, yearns for his mother's warmth and speaks and thinks of her often. Since her death, it seems that a light has gone out in him and his eyes are described as though "they might have faded like [a] shirt" (O'Connor, 1971, p. 445). This suggests that a certain vitality that they once possessed has since been depleted. In contrast, when Norton thinks of his mother and the possibility of seeing her again, his eyes glitter "with a kind of wild pleasure" (O’Connor, 1971, p. 476) as if light and life has been restored again.

Norton's yearning for his mother is evident in his desire to see her and to be with her again. When the family talks for the first time about life after death Norton asks, "when I'm dead will I go to hell or where she is?" (O'Connor, 1971, p. 462). His desire to be near his mother, especially in a time of so much change with the addition of Rufus to the household, is characteristic behavior of a child in reference to an attachment figure. C. C. Bergin and D. A. Bergin (2015) say that, "an attachment figure's availability... remains very important" to a child of Norton's age (p. 238). Once he draws a relation between where his mother is and the stars, he says that wants to become a space man one day (O'Connor, 1971, p. 476), which also shows his desire to be close to her. All of these characteristics are evidence that Norton had a secure attachment to his mother.

Children with secure attachment are sometimes referred to as "balanced" (C. C. Bergin \& D. A. Bergin, 2015 , p. 237). They have the capacity to "negotiate about their parent's availability" and their anger and distress are "readily resolved and soothed" (p. 237). At the beginning of the story, Norton expresses great distress and anger. An example of his distress is when the mere mention of his mother sends him into a hysteria at breakfast that results in his vomiting up his meal. An example of a fit of anger is when Rufus comes into their home and begins going through his mother's things and Norton is described as "breathing heavily, as though he were watching sacrilege in a holy place" (O'Connor, 1971, p. 455). When Norton learns that religion 
can "negotiate" a reunion between himself and his mother, everything changes. As Norton comes closer to his mother in various ways throughout the story, his distress and anger cease and are replaced with excitement and wonder. Norton's comfort in response to the presence and idea of his mother is comparable to how securely attached children can be comforted by their attachment figure in times of distress.

Research on attachment styles in children has often been done through a method known as "Strange Situation", in which children are briefly separated from their mothers in order to see how they respond. Children who are securely attached to their mothers are saddened by their loss, but are easily comforted when they return (Berk, 2013, p. 430). Norton is an example of this because we can see his heart wrenching desire to have his mother back, but we can also see, throughout the course of the story, that his demeanor and attitude quickly lift and change as he begins to comprehend the possibility of one day being reunited with her.

Before believing that he could see his mother again, Norton demonstrated autonomous attributes. To the best of his ten-year-old ability he would make himself breakfast (O'Connor, 1971, p. 445), sell various objects such as seeds (p. 448), and would entertain himself counting change. Autonomy is a characteristic of children who have developed a secure attachment and a secure base (C. C. Bergin \& D. A. Bergin, 2015, p. 237).

When infants, for instance, are securely attached to their caregivers, they begin to use their caregivers as a "secure base". This means that the infant has enough trust in the constancy of the caregiver to use them as a point of reference as they begin to explore the world (Berk, 2013, p. 408). "The provision of a secure base is characterized by a parent's willingness and ability to respond in a calm, attentive, constant, and supportive manner to children and adolescent's expressions of needs" (Kindvatter \& Desmond, 2013, p. 106). Children with a secure base can function without the attachment figure present, as Norton does, but continual exploration of new things in the world is usually more comfortable when the attachment figure is near.

Norton demonstrates this as well. Since his mother's death, Norton has little desire to explore or to learn new things. When Shepard buys a telescope for Rufus and asks if Norton wants to look through it, it is specified that "Norton took no interest in the telescope" (O'Connor, 1971, p. 460); but once Rufus helped him connect his mother with what he could see in the heavens through the telescope, Norton began to spend most of his time in the attic peering through it. This change displays his love for and fascination with his mother, but it also teaches us about his attachment to her. Although Norton is not an infant, his willingness to explore the world when he believes that the presence and possibility of his mother is there to support him can lead us to believe that when she was living she was, for him, a secure base and that their attachment was secure and strong.

As readers, we experience Norton's mother solely through his experience-as she herself is not present during the story. Based on Norton's secure attachment to her, noted by his desires to be near her, his capacity for autonomy even without her physical presence, and his notable rise in confidence in exploring the world with her nearness, it is safe to presume that Norton's mother was a warm, responsive, nurturing mother - a perfect fit for the "Good Mother" archetype.

O'Connor uses the "Good Mother" archetype to stir up feelings of attachment in the reader. We, like Norton, may feel more at peace with his mother's death as we realize that religion can "negotiate" a reuniting. We may feel angry and distressed with Norton at the beginning as we see him struggling with his separation from his mother, but soon may become excited as he seems to be finding ways to reach her and connect with her. Because the maternal archetype is so personal, it may effect people with different attachment histories themselves in various ways. For example, a person who is insecurely attached-in a manner that would be called "avoidant", would likely feel like Norton should pull himself together and regulate or hide his emotions, 
or become absorbed in other things to take his mind of the separation or to dismiss the loss. Those who have experienced for themselves an insecure-resistant attachment may feel like Norton was justified in his distress over his situation and like he should seek to punish his parents for the feelings of abandonment he is experiencing. Thus, the power of this relatable archetype is evident in the different ways we can psychologically respond to the same situation based on our own emotional experiences and beliefs.

\section{The Terrible Mother}

While the Good Mother archetypes can be identified in O'Connor's literature, it is equally informative to examine the same characters as "Terrible Mother" archetypes. In fact, Harding, in her article, The Great Mother: An Analysis of the Archetype, says, "Beneficent figures of Goddesses representing protection, nourishment and life-giving power are found side by side with terrible ones, representing dissolution and death" (Harding, 1995, p. 445). It is this contrast that allows us to focus not so much on outcomes of the maternal influences but on the inward processes of O'Connor's characters that allow such influence it's weight. The "Terrible Mother", as depicted by O'Connor, has to do with what Harding calls, "the aspect of the feminine that tends to hold fast to everything that springs from it and surround it like an eternal substance... Everything is born of it belongs to it and remains subject to it" (Harding, 1995, p. 446). This is the controlling, even repressive aspect of motherhood. In literature it is known as the witch, the stepmother, and many other distasteful influence. In O'Connor's case, some examples of this archetype take on the names of Mrs. Fox and also Sarah Ruth.

Harding discusses further where the power a mother has over her children can often originate. "The ego, as the center of consciousness, strives to separate itself from this containment and to develop a separate individuality [but the mother will not let it]. Should the ego yield and pull back into the maternal womb of the unconscious, the...maternal image will take on a negative cast and appear as the terrible devouring mother whose physic attraction engulfs the ego so that it sinks and is swallowed up" (Harding, 1995, p. 446). When Harding refers to the "ego" she is drawing on a psychological concept from Sigmond Freud that refers to the unconscious, decision-making, rational part of the brain. Erik Erikson, one of Freud's followers, expounded saying that the ego "makes a positive contribution to development", and is responsible for the development of skills that enable an individual to be a contributing part of society (Berk, 2013, p. 16). The power of attachment relationships is apparent in terms of what skills the child is able to develop through that attachment relationship. For example, children who are securely attached have been observed to, "openly communicate about emotions, develop better language skills, and have less hostile attribution bias... their mothers use more 'mental state' talk which helps them develop better theory of mind, promoting high quality [relationships]" (C. C. Bergin \& D. A. Bergin, 2015, p. 480). Securely attached children are better prepared for healthy relationships with others because they have learned the skills necessary for healthy relationships through experience with their attachment figures.

The implications of Harding's statement on O'Connor's characters then, are severe. Negative or overpowering mothering can rob the child of developmental experience and can ultimately lead to the diminishing of the child's desire, skill, and ability to reasonably contribute to society—or at least their perception of such. An example of this is Mrs. Fox's relationship is Asbury in O'Connor's story, "The Enduring Chill".

Mrs. Fox, in all of her nurturing, is described by her son Asbury to be killing his spirit. "I came here to escape the slave's atmosphere of home", Asbury writes to her, "to find freedom, to liberate my imagination, to take off like a hawk from it's cage...I was incapable of flight. It was some bird you domesticated... I have 
nothing but desire for these things. Why didn't you kill that too?" (O'Connor, 1971, p. 364). Here we can see that although Mrs. Fox believes she is giving life to her son, he feels as though she is trying to smother his ability to make choices and choose for himself a place in society. Because of this, she is cast in a negative light, and takes on the archetypal role of the "Terrible Mother". C. C. Bergin and D. A. Bergin (2015) teach that if a mother ignores emotional signals from her [child] and is "insensitive and intrusive... this [child] may develop an angry emotional core and poor regulation if his mother continues to be intrusive over time" (p. 331). We can sense that angry emotional core from Asbury in the above mentioned statement to his mother. Another example of Asbury's anger and lack of ability to maturely regulate his emotions is when his family picks him up from the station and they are driving home. His mother is trying to make conversation with him, as she is excited to have him back. He ignores her gaze, pouts, snaps, and eventually cries out at her saying, "Good God! Can't we go on? It's six o'clock in the morning!" (O'Connor, 1971, p. 362). Another example is later on when Doctor Block is visiting them on his mother's request, investigating Asbury's symptoms of illness and trying to diagnose him. He demonstrates, in his interactions with Doctor Block, a lack of social competence or empathy as well as a lack of emotional regulation. He says to Doctor Block, "If I wanted a doctor, I'd have stayed up there where I could get a good one!" (p. 366). Eventually he informs the doctor that his illness is "way beyond you" (p. 367). Children who are securely attached are more likely, according to research, to have "constructive coping strategies that help them express their emotions, receive others emotions, take on emotionally charged situations, and talk about hot topic without anger" (C. C. Bergin \& D. A. Bergin, 2015, p. 331). Asbury demonstrates none of these things, but rather demonstrates a lack of ability to cope with his emotions and control his egocentric and frustrated outbursts - to the emotional detriment of those around him. This is a prime example of how an insecure attachment can lead to underdeveloped social and emotional skills. One reason for this is that the continual anxiety throughout childhood that stems from an insecure attachment can actually alter the chemistry in a developing brain which can lead to underdevelopment in the cortex, the center of emotional regulation (p. 332).

One reason that Asbury's insecure attachment to his mother-who seems so nurturing and life-giving — could be because of a principle of attachment called the "Goodness of Fit".

The Goodness of Fit model was discovered and discussed at length by two scientists named Thomas and Chess, and states that it is an "effective match, or "good fit", between child-rearing practices and a child's temperament [that] leads to favorable development and psychological adjustment [in children]. When a "poor fit" exists, the outcome is distorted development and maladjustment" (Berk, 2013, p. 426). The Goodness of Fit model explains why some children with more difficult temperaments struggle, even with seemingly good parenting - because effective parenting depends on the child receiving it and whether or not it is the right kind of parenting for them. Although Mrs. Fox is warm and friendly, and seems to be a "good parent", her son Asbury has a much different temperament and does not respond well to the type of interaction that she offers. Without effective communication or conclusive understanding, over the years, this "poor fit" has created walls between them and has resulted in the maladjustment that is apparent in Asbury's attitude and behavior. Evidence of this is the difference between the relational results of Asbury's interaction with Mrs. Fox and what is deemed by psychologists as an ideal outcome of a good parent-child fit. It is believed in the psychological world that "when parents understand the internal experiences that drive children and adolescents' emotional dysregulation they are in better position to meet the needs of the child or adolescent and thus reduce conflict" (Kindvatter \& Desmond, 2013, p. 109). Clearly, this is not the case with Mrs. Fox. As she sees Asbury 
purposefully withdrawing, she comes ever closer-wanting to assert her help and her life-giving nurturing while he remains unresponsive. Although he is cold and pessimistic about his future, she continually asserts rejected optimism. One example of this is when she insists that although he feels his mortality creeping in upon him, he will live. When Asbury contradicts her in this regard she responds, "Do you think for one minute... that I intend to sit here and let you die?" (O'Connor, 1971, p. 372). From this quote we can see that she is determined to nurture him back to health, and that sympathy and mourning are held at bay for the sake of her agenda-optimism and denial. As Asbury weakens, she takes his life into her own hands and calls upon a doctor, ultimately and additionally "making up her mind that he must go to the hospital" (O'Connor, 1971, p. 377). The fact that she is taking his decisions about his life into her own hands is an example of her "smothering", "Terrible Mother" behavior. It is this type of behavior that infuriates Asbury all the more and actually increases his desire to die.

Evident in Mrs. Fox's behavior is an imminent fear of losing her son. Jude Cassidy, a published psychology professor at the University of Mariland, expounds on behavior such as this when she says, "Just as the child's attachment and fear systems are closely linked (such that an increase in fear contributes to increased attachment behavior), so are the parents caregiving and fear systems. When a parent is frightened by threat to the child, she increases caregiving behavior" (Cassidy, 2000, p. 87). Such behavior would not be so detrimental to their relationship had Asbury and Mrs. Fox had a "good fit" in their parent-child dynamics-but because of their lack of such, her nurturing behavior contributed to his insecure attachment. In fact, this is evident in other results of Mrs. Fox's parenting as well-as fear of losing her children propelled her to deny them autonomy. When Asbury arrives home she wants to do many things for him, including opening his bags and getting his things out. Long term effects of such parenting are apparent in the fact that Asbury struggles to live autonomously, fails miserably at it when he moves to New York, and has to come back home. The fact that his sister, Mary George, is also living at home shows the effect of such parenting on both children. This, again, shows the emotional and social lack of development due to insecure attachment. Because of these negative results, Mrs. Fox is cast into the Terrible Mother archetype.

Asbury displays what is known as a "deactivation strategy", a mode of emotional regulation designed to help children cope with perceived injustices in their parent-child relationships and their attachment experiences. Traits of deactivation include, as Kindvatter and Desmond would describe, "a desire to punish" a caregiver, or an "effort to protect oneself from further harm by distancing". They also say that those with this kind of insecure attachment display rage and ager towards those by whom they feel rejected or abandoned (Kindvatter \& Desmond, 2013, p. 106). We can see evidence of this anger in Asbury as he writes a terrible note to his mother that he intends to leave for her to find after his death. His desire to punish her is evident by his hopes that she will feel pain through his suffering. In fact, "he was pleased that she could see death in his face", as his heath failed him, and he muses that, "his mother, at the age of sixty, was going to be introduced to reality and he supposed that if the experience did not kill her, it would assist her in the process of growing up" (p. 357). His vengeful attitude is evident in the demeaning way that he talks of his mother, and acknowledges, with no remorse, compassion, or concern, that this death he is facing may kill her as well. We can see him distancing himself, a behavior that is characteristic of deactivation, in his repeated pleas to be left alone, and in his stubborn rejection of any kind of help, encouragement, or comfort.

Another example of the negative influence of the maternal figure is in "Parker's Back" where Parker's insecure attachment to his wife, Sarah Ruth, ultimately leads to his unraveling. Although Sarah Ruth is not 
Parker's mother, she is a maternal figure in the story. To readers, Parker's relationship to Sarah is puzzling, as Parker himself never seems to figure out quite why he likes her at all. Seeing her as a motherly archetype can shed some light even on that. When Parker was young, his mother did not necessarily approve of his tattoos or his budding rebellious lifestyle. In fact, as the story goes, "his mother wept over what was becoming of him" (O'Connor, 1971, p. 513). One night, she tried to get him to a revival with her, without telling him beforehand where they were going, and in fear he escaped the grasp of her guiding maternal hand, ran away, and joined the navy. After that experience, he sought comradery among people who were more like him, so it would seem that his mother was one of the only - and certainly the strongest - religious influence in his life. It would seem likely then, that it would be his insecure attachment to his mother, and the internal working model that created for him as a youth that lead him to believe that other relationships of that type were to be his life-long destiny. This could cause Parker to be subconsciously attracted to another religious woman, equally as set on saving him, and even more disapproving of his tattoos. This woman, the perfect fit to his internal working model, was Sarah Ruth. It was Parker's unfulfilled yearning for maternal love that kept him coming back to Sarah Ruth, trying to fill a hole in his heart left by the insecure attachment of his youth.

Studies have shown that a secure attachment to a spouse can resolve the issues that resulted from an insecure attachment to a parent, but that in less ideal situations, the effect of insecure attachments in childhood bleeds over into romantic relationships (C. C. Bergin \& D. A. Bergin, 2015, p. 240). Yee and Shiota (2015) say that, "among adults, attachments committed to romantic partners and intimate friends are thought to reflect engagement of the same system;" the same system that created by the initial attachment of a child's life. Sarah Ruth has a profound effect on Parker as an attachment figure - and because of her uniquely feminine role-she too plays into the "Terrible Mother" archetype. Parker displays characteristics of insecure attachment known as insecure avoidant attachment, which is characterized by a desire in childhood to ignore or avoid an attachment figure, hiding their emotions (C. C. Bergin \& D. A. Bergin, 2015, p. 235). In adults, the effects of this kind of attachment are manifest in discomfort in sharing personal information, or reluctance to commitment and long-term relationships (p. 238). Parker was not a man who liked to share his personal information - in fact, nobody but the navy and the government (and his mother who named him and had him baptized as an infant) knew that his real name was Obadiah Elihue, and everyone called him O.E. This secret part of identity was cherished and protected by Parker, and we can see his reluctance to disclose it in the difficulty he had sharing his name with Sarah (O'Connor, 1971, p. 517). Of Parker, it is said that, "he had other women [before meeting Sarah Ruth] but he had planned never to get himself tied up legally" (p. 511). The use of the word "tied" in this context has a more negative connotation than the typical, "tying the knot", and informs readers of Parkers fear and resistance of committed, long-term relationships. This is also evident in his description of his marriage to his tattoo artist when he says, "I never should have done it. I ought to leave her" (p. 525). This attitude is consistent and resolute throughout the story, and yet Parker continues to go back to Sarah Ruth.

In his relationship with Sarah Ruth, Parker eventually realizes that, "all along... he wanted to please her" (O'Connor, 1971, p. 527) - a feeling not uncommon between children and their maternal or attachment figure. However much he wanted to please her though, his tattoos-his favorite form of self-expression-never impressed her, and in fact they repulsed her so severely that he admits to himself that she only liked him when he was totally covered up or in the dark, which demonstrates opinions very similar to those held by Parker's mother (O’Connor, 1971, p. 519). 
Kindvatter and Desmond (2013) teach that, "the relational difficulties associated with attachment might be thought of as stemming from attempts to gain something that is perceived to be needed (e.g., assurances that one is valued) or to avoid something that is viewed as threatening (relational vulnerability)" (p. 110). In Parker's case, he wishes to gain Sarah Ruth's approval and yet cannot seem to do so through his self expression. He desires this affirmation because he is afraid of being vulnerable and risking the pain of abandonment. Such feelings lead Parker to what is known as a hyper-activation strategy of coping — which includes behaviors such as angry demands for attention, an intense desire to be comforted by others, and pleas for reassurance in the face of abandonment threats. We can see this clearly at the story's close when Parker comes home from the city, desperately begs entrance into his own home, and then frantically tries to immediately show Sarah Ruth his tattoo-his last attempt to please her. This scenario shows his need for reassurance after such a personally difficult and spiritually taxing weekend of revelation, as well as his need for attention. The quality of their relationship and the reason for his insecure attachment is evident when not only is he sadly rejected, but he is beat with a broom until, "large welts had formed on the face of the tattooed Christ" on his back (O'Connor, 1971, p. 529). Then, he is kicked out of the house where he begins, "crying like a baby" (O'Connor, 1971, p. 530) - sadly, displaying another of the hyper-activation characteristics - the need to be comforted by others.

The fact that Parker was crying like a baby is also significant to his attachment. Insecure attachments form, and parent-child conflicts arise, when the needs of children and/or of their attachment figures are unmet (Kindvatter \& Desmond, 2013, p. 105). When the needs of babies are not met, they cry! And if they go without being consoled, over time, they will come to a sense of distrust for their attachment figure and for the world. So, we can see that through Sarah's failure to comfort him, their insecure attachment and resultant relationship continues.

Knowledge of this attachment is critical because it explains Parker's behaviors and gives insights into his psychiatric processes, as well as into their mysterious couple relationship, and ultimately helps us understand why Sarah Ruth has the effect that she does as an archetype of the Terrible Mother.

\section{Attachment to the Divine}

Another of the famous archetypal mothers is the Christian figure, Virgin Mary. She is uniquely symbolic of God's union with humanity. In fact, according to critic Pierre Balthazar, "God sees the Virgin Mary as the object of delight that restores the symbiotic union with humanity. She is to recapture humanity, to take humanity back to it's state of wholeness where humanity can enter into deep intimacy with the Creator and God of the universe" (Balthazar, 2007, p. 538). Because O'Connor identifies as a Catholic (as she proclaims in her essays, "The Catholic Novelist in the Protestant South" and "Catholic Novelists and Their Readers"), comparisons between the mother archetypes in her work and the Virgin Mary are instructive and realistic (O'Connor, 1969, pp. 169-209). Interestingly, like the Virgin Mary, the mothers in O'Connor's stories have a way of delivering grace and drawing those they influence closer to God.

In The Bible, in the book of Isaiah, chapter 49, verse 15 the grace of God is compared to the love of a mother. It reads, "Can a woman forget her sucking child, that she should not have compassion on the son of her womb? Yea, they may forget, yet I will not forget thee" (KJV Bible, Isa. 49.15). This verse is interpreted to mean that God's love is so constant, nourishing, and vital that is like unto the most influential form of earthly love - a mother's love. Through God's grace, He proves even more faithful than a mother, and His love proves even more reliable. While it is beyond the scope of this paper to examine the concept of "grace" in O'Connor's 
work, in the last analysis, the attachment the characters portray in relation to their mothers is actually reflective of their attachment to God and their religious journey to grace.

For example, in "The Lame Shall Enter First", it is through Norton's mother that Norton is first receptive to the idea of God, or Christ — so in that way his mother was bringing him into a state of greater intimacy with his creator. When Norton asked where his mother was now that she was dead, Rufus - the faithful one among them — asked whether or not she believed in Jesus and had been saved. Norton answered, "Yes... I heard her say she did all the time" (O'Connor, 1971, p. 462). From that time forth, Rufus began to teach Norton about God and about the Bible. In this way, Norton's mother was the factor that drew him closer to God. Additionally, Norton's drawing nearer to his mother through the telescope eventually resulted in his surprising death - bringing him back to the presence of God. Thus, the climax of being near to his mother, just when Norton said he could see her, was also the moment when he became nearest to the creator through the severing of mortality (O'Connor, 1971, p. 478).

Mrs. Fox in the Enduring Chill, is the catalytic instrument by which Asbury learns of his fate and his need for grace. Her persistence and insistence that he meet with Doctor Block eventually leads to his condemning diagnosis of undulant fever, which realization leads Asbury to a state of surrender in which he can feel the Holy Spirit for the first time (O'Connor, 1971, p. 382). Additionally, Asbury's feelings towards God, in "The Enduring Chill”, seem to mirror his feelings for his mother. One example of this is that when he came home he did not come in order to enjoy any comforts of maternal closeness. In fact, he came home with a fixed attitude and one transcendent request, "all I want you to do is to leave me alone" (O'Connor, 1971, p. 361). Similarly, his avoidant and resistant attitude towards his mother is also mirrored in his attitude towards God that he describes when he says, "The Holy Ghost is the last thing I'm looking for" (O'Connor, 1971).

This same theme is evident in "Parker's Back" in an allusion to the parable of the ten Virgins. When, O.E. comes home after his time in the city and knocks on the locked door asking to be let in, Sarah Ruth Cates replies “I don't know no O.E” (O’Connor, 1971, p. 528). In the Bible, there is a parable of ten virgins who are invited to attend a wedding. Five of them were unprepared to meet the bridegroom and showed up late to the feast as a result. When they did arrive, the door was already shut. This is comparable to Parker's situation when he returns from the city to find the door to his home shut and locked. In the Bible, when the virgins cry out for The Lord to let them in, The Lord responds similarly to the way that Sarah Ruth responds in the story when he says, "I know you not" (KJV Matthew 25.12).

In this parable, the marriage is symbolic of the kingdom of heaven and the bridegroom, or the Lord, is Jesus Christ Himself. This allusion relates O.E.'s desire to be accepted back home by his wife - to feel accepted by his attachment figure - to his new-found desire to be closer to and to be accepted by God. The relationship between himself and Sarah Ruth is insecure, as is his relationship with God - as demonstrated by the fact that he can hardly bare to look into the eyes of the picture of Christ on his back (O'Connor, 1971, pp. 525-526).

\section{Conclusion}

Pierre Balthazar addresses why, even with all the negative risks involved, O'Connor's characters are drawn to and reliant upon maternal figures in their lives when he says it is "their need to find a female figure whom they can call mother, someone they can go to whenever feelings of inadequacy, lack of confidence, self-doubt, and fear of the unknown surface. This mother provides the secure base to go into the environment and explore" (Balthazar, 2007, p. 538). Even though the maternal figures in O'Connor's work ultimately 
administer to death rather than to life, her characters are drawn to them and shaped by them. Characters such as Norton, Asbury, and O.E. Parker can be better understood as their psychological motivations are examined - and these motivations stem from their attachment to their mothers. This attachment also sheds light on O'Connor's concept of grace as the attachment of her characters to their mothers reflects their attachment to the Devine.

O'Connor (1969) herself said, in her book Mystery and Manners "Anybody who has survived childhood has enough information about life to last him the rest of his days. If you can't make something out of a little experience, you probably won't be able to make it out of a lot" (p. 84). It is through our childhood experiences, specifically with attachment figures, that we develop relatively stable perceptions of ourselves and the world. Whether or not O'Connor's work is influenced by her own relationship with her mother is a topic for another study, but it is an arguable point that we all, as human beings designed to connect and attach and determined to belong, are influenced consciously or subconsciously by the attachment that we have experienced in our lives. These attachments influence the way that we perceive family relationships, social justices and injustices, and - for believers - the relationship of God to us as His children. O'Connor's work is known to incite strong reactions from readers. This has been said to be based upon her deliverance of grotesque and violent grace. After this discussion, it is clear, based on a study of only three of her works, that the influential maternal archetype is present - a symbol that has the power to elicit deep emotional responses from us all. One reason that we find these stories to be impactful may be, not only because of the principle of grace, but because of our own attachments to parent or spouse. As O'Connor has said, and was quoted at the start, "the truer the symbol, the deeper it leads you" (O'Connor, 1969, p. 71). Our defensive or supportive or ambivalent reaction to these scenarios may teach us something about our own internal working models and offer insight into why, when it comes to relationships and family, we feel and believe the way that we do-but that is a study for another day.

\section{References}

Balthazar, P. (2007). The mother-child relationship as an archetype for the relationship between the Virgin Mary and humanity in the Gospels and the book of revelation. Pastoral Psychology, 55(5), 537-542.

Bergin, C. C., \& Bergin, D. A. (2015). Child and adolescent development in your classroom. Cengage Learning, Stamford CT.

Berk, L. (2013). Child development. Saddle River NJ: Pearson Education Inc.

Cassidy, J. (2000). The complexity of the caregiving system: A perspective from attachment theory. Psychological Inquiry, 11(29), 89-92.

De Coster, D. D. P. L. (2010). The collective unconscious and it's archetypes. Gent, Belgium: Satsang Press.

Guerin, W. L., Labor, E., Morgan, L., Reesman, J. C., \& Wllingham, J. R. (2011). A Handbook of critical approaches to literature. New York: Oxford University Press.

Harding, M. E. (1995). The Great Mother: An analysis of the archetype. Journal of Analytical Psychology, 40(3), $445-447$.

Kindvatter, A., \& Desmond, K. J. (2013). Addressing parent-child conflict: Attachment-based interventions with parents. Journal of Counseling and Development, 91(1), 105-112.

O'Connor, F. (1969). Mystery and Manners. New York: Farrar, Straus, and Giroux.

O'Connor, F. (1971). The complete stories. New York: Farrar, Straus, and Giroux.

Redshaw, M., \& Martin, C. (2013). Babies, "Bonding" and ideas about parental attachment. Journal of Reproductive and Infant Psychology, 31(3), 219-221.

Reuman, A. E. (1993). Revolting fictions: Flannery O'Connor's letter to her mother. Papers on Language and Literature, 29(2), 197-215.

The Holy Bible. (1979). Salt Lake City UT: The Church of Jesus Christ of Latter-Day Saints.

Yee, C., \& Shiota, M. N. (2015). An insecure base: Attachment style and orienting response to positive Stimuli. Psychophysiology, 52(7), 905-909. 